$4^{\prime} 7$ per cent. of the whole. Indeed 32 families, $23^{\circ} \mathrm{I}$ per cent., we found to have only at the rate of between 100 and 200 cubic feet per head. In a particular case we found one family housed in part of a lean-to shed or byre, so that its five inhabitants had less than too cubic feet per bead. Therefore, not far from 80 per cent, of overcrowding exists, according to $\mathrm{my}$ standard.

Cubic Feet per Room. - It will be of interest to give averages of the cubic capacity of the kind of rooms in which this class of people live. Helmsdale had 1,269 cubic feet as the average of its room (which in many cases is part of a loft or store for keeping barrels and other fishing gear). Brora had 982 cubic feet; Embo, 925 cubic feet; and Golspie, 886 cubic feet.

For what is called a closet (in which, however, two-perhaps more-usually sleep), a small room without a fireplace, and often deficient in ventilating windows, etc., the average in Helmsdale was 593 cubic feet; Embo, 484 ; Golspie, 483; and Brora, 467 cubic feet.

And for what is known as an upstairs room or irregular triangular space, as most of them are, under the roof, not infrequently without a fireplace or sufficient ventilation, the average in Helmsdale was $x, 100$ cubic feet ; Brora, 926; Golspie, 868; and Embo, 68I cubic feet.

The closets and upstairs rooms are chiefly used for sleeping in, and, if possible, the room proper is not regularly used for sleeping, but is either a kitchen or "best room." It can readily be understood, then, how little air space there is for each person sleeping when, as generally, there are at least two adults and possibly some children in a closet or sleeping-room of the capacity above stated.

The Families so Arranged as to Show the Average Contents of Persons per Room.-In Helmsdale two families were actually found, each in one room, and they each had twelve persons to the family, with an average cubic space in the one case of only 113 cubic feet, and in the other $\times 29$ cubic feet per person (proved by dividing 1,360 cubic feet among twelve, and $1,55^{\circ}$ among twelve.) In fact the available air would be considerably less than these figures, for there is no allowance made for the cubic space occupied by bedding, furniture, clothing, and some fishing gear, etc.

Three families in Helmsdale were found with eleven persons, two with ten persons, nine with nine persons, eleven with eight persons, fourteen with seven persons, all in one room for each of them, and necessarily with only a small amount of cubic air to each. The largest number 22 , or $x_{5}: 8$ per cent. out of the total $3^{8}$, were found in one room, with three persons per family; and again 22 families were found with five persons per family, all in one room.

When only two persons to a room are found, it is considered a high average (Scotland's average per village in $189 \mathrm{r}$ being only $\mathrm{r}^{\circ} 5$ persons per room), whereas in Helmsdale the great majority of families had from three persons up to as high as twelve in one room. Can it be wondered at that, in times gone by, there have been typhus and other fevers on several occasions in this place and spreading sometimes to other villages from it? In I 892 an epidemic of scarlet fever was averted by summarily ordering all the Embo, Brora, etc,, children-the combustible material-home.

In all the villages examined, if overcrowding can be proved from the average maximum figures for a whole house, how much aggravated must be the actual overcrowding when only a less amount (that found in sleeping rooms) than the total available air is being used for accommodation, in health and disease ?

\section{BACK-TO-BACK HOUSES.}

By Herbert JoNes, L R.C.S.I., D.P.H. Camb. (Read before the Bradford Medico-Chirurgical Sociaty, May 2nd, I893.)

AnYone who has but the most passing acquaintance with statistics is only too well aware of the tricks that figures are in the habit of playing one, so that it is only by hemming them in and weighing them down with the most stringent rules that it is at all possible to extract from them useful and reliable information. It is no doubt within your knowledge that we have two sets of vital statistics comparing back-to-back and "through" houses, one compiled by Dr. Bell, of this town, in 1891 , the other from figures supplied by Dr. Tatham, of Manchester, in 1888 . But as the deductions drawn from these two tables are distinctly at variance, and as there are in both of them many vulnerable points, before I began to compile the following, I laid down certain conditions which it seems to me must exist or must be approached as nearly as possible if we wish to obtain accurate and precise results.

I. The areas compared must each contain a minimum of the opposite class of house. That is to say, the back-to-back houses must have few, if any, through, and the through bouses few, if any, back-to-back.

2. Each class of house must be occupied by the same class of tenant, earning as nearly as possible the same wages and occupied in the same kind of work. It would be manifestly unfair to compare the through houses of the potters in Staffordshire with the back-to-back houses of the Bradford weavers.

3. The sanitary arrangements of each house must be identical, especially regarding the w.c. and ash-pit. We cannot compare a house with a w.c. and one with an old-fashioned privy emptied only when overflowing.

4. The building material, the soil, the aspect, and the water supply must be the same.

5. The density of persons per acre and the age of the houses must approximate as nearly as possible. 
6. A large number of houses must be taken, and the calculations must be spread over at least five years.

I should like to add that it is important to obtain information as precisely as possible : (a) As to the relative amount of pauperism in each area operated upon; (b) as to the number of houses that have been unoccupied during the years dealt with; $(c)$ as to whether any localised epidemic has occurred in one or other of the districts; $(d)$ if either district contains a hospital or public institution, allowance must be made for deaths occurring therein.

These safeguards have all been most stringently applied to the figures $I$ am about to review.

We have in Shipley (a township with a population of $x 6,000$ ) two districts that fulfil very closely the conditions I have recited. The compact village of Saltaire, built in 1853 , contains $85^{\circ}$ houses, all of them of the through type, has a population of 4,218 , with a density of 197 to the acre, and rents ranging from $3 \mathrm{~s}$. to $5 \mathrm{~s}$. per week. Then we have almost adjoining a district built between 1853 and 1870 , containing exclusively back-to-back houses- -874 in all, with a population of 4,155 , a density of 222 to the acre, and rents ranging from 2s. $6 \mathrm{~d}$. to $7 \mathrm{~s}$. per week. All these $x, 700$ houses are occupied by the same class of tenants, who are engaged in the same kind of work.

The soil, the water-supply, the aspect, the sanitary arrangements, and the building material are the same. The average number of paupers in the through houses is ' 42 of the population, and in the back-to-back district 47 .

My statistics cover the six years from 1887 to $\mathrm{I} 892$ inclusive, and taking first of all the deaths from all causes, it will be found that the average annual death-rate during those years in the whole of Shipley was 16.2 . In the through houses of Saltaire in the same period it was $15^{\circ} 6$, and in the back-to-back houses of Shipley $2 I^{\prime} I$, thus clearly showing that the death-rate of the entire district is dragged up by these back-to-back houses.

Then when we come to specific causes of death, the zymotic death-rate was in Saltaire 1.08 , in the back-to-back district, and the whole town $x \%$. We have so few deaths from diarrhcea in Shipley that little can be learned from its death-rate, though we find that the back-to-back houses have nearly twice as many deaths as occur in the through houses. When we come, however, to lung diseases we find, as we should expect, that the through houses compare most favourably with their opponents. Let us take phthisis first ; in Saltaire the average death-rate was $2 \%$, in the back-to-back houses 3.4 , and in the whole town 2.3. Other respiratory diseases (bronchitis, pneumonia, and pleurisy) gave for Saltaire $3^{\cdot 6}$, for the back-to-back houses $5^{\circ} x$, and for the whole district $4^{\circ} \circ$.

I am quite prepared to be told that there are back-to-back houses and back-to-back houses.
And as I find upon analysing different classes of these houses that different results may be obtained according to the amount of air-space between the houses, it would be extremely unfair to those who favour this kind of dwelling if $I$ withheld the result of my investigation. The back-to-back houses are divided into three sections; $A$ has streets 25 yards wide, with a density of $\mathrm{I} 60$ persons to the acre; $\mathrm{B}$ has streets 10 yards wide, a density of 300 to the acre ; and in C the streets are 15 yards wide, and the density is 207 to the acre. In $B$ and $\mathrm{C}$ some of the streets are $c u l s \cdot d e-s a c$; indeed, we might say that not only the houses but the very streets are back-to-back. In A there are no blind streets. We find that the death-rate in $\mathrm{A}$ from all causes was $18 . x$, in $\mathrm{B}_{28} 8^{\circ} \mathrm{x}$, and in $\mathrm{C} 22^{\circ}$. $^{\circ}$

If we compare, then, the through houses with those back-to-back that have the greatest advantages-the A district-where the houses are 25 yards apart; where there is a density of only 160 to the acre against 197 in Saltaire, and where the percentage of pauperism is only $\cdot 17$, against $\cdot 42$ in Saltaire, we find that the through houses still more than hold their own, and most noticeably in the case of respiratory diseases, the Saltaire deathrate being $3^{\circ} 6$, and the back-to-backs $4^{\circ} 9$.

Those who advocate back-to-back houses never tire of telling us that in drawing up comparative statistics there are so many influences to be taken into consideration other than the construction of the dwelling. There must be some reason, however, why the death-rates in this one group $A$ of nearly 500 back-to-back houses should be so much higher than in the through houses of Saltaire. Can it be poverty? But there is more than double the amount of pauperism in Saltaire. Can it be the density of population? But Saltaire has ' $x$ persons more per house and 37 more per acre. Is it due to the faulty sanitary arrangements? But the death-rate from diarrhcea-a disease more dependent, perhaps, than any other upon adequate drainage-curiously enough is precisely the same in both districts. We must fall back, I think, upon the special construction of the two classes of dwellings as the primary factor in bringing about so great a disparity as I have indicated.

Just a word with regard to the phthisis deathrate, which is in Saltaire $2 \%$, and in the best backto back houses $2: 8$. I cannot help feeling that the explanation of this high death-rate in Saltaire is to be found in the tenacity for life that is exhibited by the spores of the bacillus of tubercle. When we remember that we have in Saltaire on an average one death a month from tubercle, and when we recall the long illness that has preceded that death, we cannot be wrong in concluding that there must be scores of infected houses capable of spreading the disease upon the first favourable opportunity.

I have taken the greatest pains to obtain my figures accurately. Details as to the number of 
empty houses were obtained from official sources, the measurements required to estimate the number of persons per acre were made by the town surveyor, the relieving officer supplied the figures relating to pauperism, and the actual death-rates I took out myself from the registrar's book.

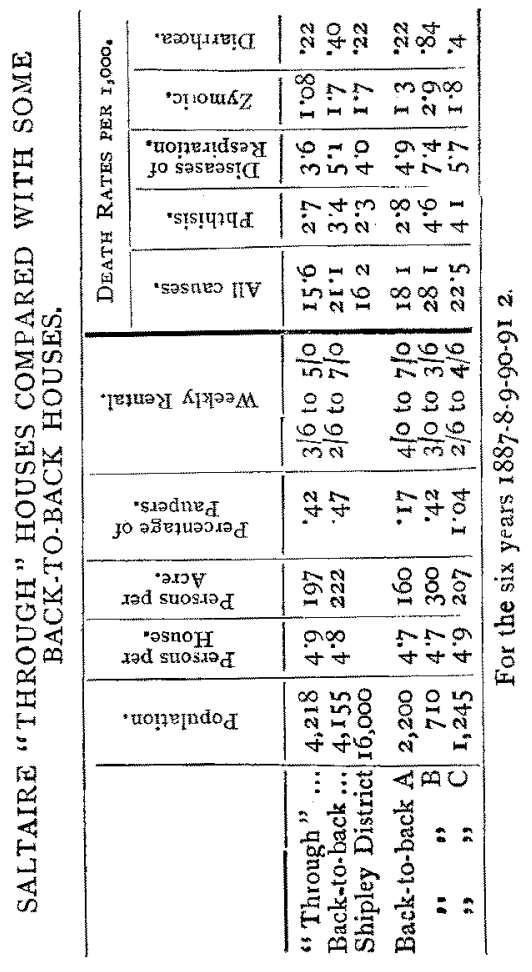

LAW REPORTS.

Queen's Bench Division.-Before Lord ColeRIDGE and Mr. Justice CAVE.-Notice to alter building erected without previous notice to District Surveyor must be served before completion of building.-SMITH v. LEGG.

The appellant in this case was engaged in January, 1892 , to erect a building in Hackney. The respondent was the district surveyor of West Hackney, under the Metropolitan Buildings Act, 1855. The appellant erected the building in question without first giving the district surveyor the notice required by section $3^{8}$ of the above Act. A month after its completion, in April, 1892 , the surveyor discovered that the building had been proceeded with; and in July gave notice to the appellant under section 45 of the Act, requiring him to make certain alterations in the building. This notice not being complied with, proceedings were instituted with the view of obtaining an order commanding compliance with the requisition of the notice. The magistrate made an order on the appellant to comply with the notice, although it was urged on behalf of the defendant that the building having been completed the proceeding was too late. The builder appealed against this order. Section 45 of the Metropolitan Buildings Act, 1855 , provides as follows :-

In the following cases, that is to say, if in erecting any building, or in doing any work to, in, or upon any building, anything is done contrary to any of the rules of this Act, or anything required by this Act is omitted to be done; or, in cases where due notice has not been given, if the district surveyor, on surveying or inspecting any building or work, finds that the same is so far advanced that he cannot ascertain whether anything has been done contrary to the rules of this Act, or whether anything required by the rales of this Act has been omitted to be done ; in every such case the district surveyor shall give to the builder engaged in erecting such building, or in doing such work, notice in writing, requiring such builder within forty-eight hours from the date of such notice, to cause anything done contrary to the rules of this Act to be amended, or to do anything required to be done by this Act, but which has been omitted to be done, or to cause so much of any building or work as prevents such district surveyor from ascertaining whether anything has been done or omitted to be done as aforesaid, to be to a sufficient extent cut into, laid open, or pulled down.

At the hearing of the appeal case, it was urged on behalf of the appellant that section 45 only applied to buildings in the course of erection; while, for the respondent, it was contended that, under section 105 of the Act, the proceeding was in time, that section providing that the time during which the district surveyor may take any proceeding or do anything authorised or required by the Act to be done by him in respect of a building or work erected or done without due notice being given to the district surveyor, shall begin to run from the date of his discovery that the building had been erected or work done.

Lord Coleridge, in giving judgment, said : If the view of the counsel for the respondent is correct, very strange consequences might ensue. It is admitted that no notice was given by the district surveyor to the appellant until the building was completed, but it is said that the district surveyor was not aware of the building being erected until it was finished. The district surveyor, however, should have "kept his eyes open, and then he would have known that the building was in course of erection. Section 45, under which the surveyor served the notice which the appellant bas been called upon to comply with, it appears to me is only intended to apply to a notice given whilst the building is in course of erection. If a notice given, as in this case, after a building is completed, is in time, it would follow that though the building had been completed and paid for and sold, still the notice might be given to affect an innocent purchaser. Again, the builder might be dead, and could it be supposed that his executors were to be held liable in such a case? To suppose that these proceedings could be taken after the building was completed would be to suppose that the Legislature had intended an outrage upon good sense and justice. There 